\title{
The Role of The Doctor as a Teacher
}

\author{
Claribel Plain Pazos*1, Anel Pérez de Alejo Alemán², Carmen Rosa Carmona Pentónn ${ }^{1}$, Anisbel Pérez de \\ Alejo Plain ${ }^{3}$, Yovana Roque Betancourt ${ }^{4}$, Nereyda Caraballo Moya ${ }^{1}$ \\ ${ }^{1}$ Specialist of I and II Degree in Comprehensive General Medicine, Faculty of Medical Sciences of Sagua la Grande, Cuba \\ ${ }^{2}$ Specialist of I Degree in Internal Medicine, Teaching General Hospital, Sagua la Grande, Cuba
}

${ }^{3} 3^{\text {rd }}$ Year Student of Medicine, Faculty of Medical Sciences of Sagua la Grande, Cuba

${ }^{4}$ Bachelor of Nursing, Faculty of Medical Sciences of Sagua la Grande, Cuba

Corresponding author: Claribel Plain Pazos, Specialist of I and II Degree in Comprehensive General Medicine, Faculty of Medical

Sciences of Sagua la Grande, Cuba

\begin{tabular}{|c|c|}
\hline ARTICLE INFO & ABSTRACT \\
\hline Received: 晋 October 09, 2020 & Citation: Claribel Plain Pazos, Anel Pérez de Alejo Alemán, Carmen Rosa Carmona Pentón, \\
\hline Published: 蔧 October 21, 2020 & $\begin{array}{l}\text { Anisbel Pérez de Alejo Plain, Yovana Roque Betancourt, Nereyda Caraballo Moya. The Role } \\
\text { of The Doctor as a Teacher. Biomed J Sci \& Tech Res 31(2)-2020. BJSTR. MS.ID.005086. }\end{array}$ \\
\hline
\end{tabular}

\section{Opinion}

The scientific and technical development in the contemporary world has brought as a consequence that all aspects of human life have also evolved. Education does not escape this reality. The student in higher education today does not need high-ranking professors who recite a lesson from memory. Today's student needs teachers to teach them the way of self-management of their knowledge. That they teach them to work with the tools that the new development has brought with it in order to achieve the necessary skills to become a good professional.

This situation becomes even more important in the health sector. Training competent and up-to-date human resources in Public Health is a challenge and a necessity in today's world. Within the health sector the doctor plays a preponderant role. He is the main link to guarantee the health of man as a biopsychosocial being. That is why it is necessary for the professor to direct his actions to guarantee complying with the profile of the doctor's graduate as a health professional. The general practitioner is a highly qualified professional, capable of fulfilling care functions (comprehensive medical care), teaching-educational, administrative, research and special functions in exceptional situations. The main job position is the Family Doctor and Nurse's office in the community, in educational institutions and in work centers. It also includes those that do not require specialization in polyclinics, hospitals and other institutions where health services are provided by general practitioners [1].
For the training of this doctor, it is necessary to have a prepared faculty, who is capable of interacting with the current scientific technical development, in order to direct the training process of that future professional, guaranteeing an exit profile based on medical care quality, which is what society demands today. In Cuba, Medical Education constitutes a subsystem within the National Health System and is part of the policies and plans of the Ministry of Public Health (MINSAP) with methodological subordination to the Ministry of Higher Education (MES) [2]. That is, in At the Cuban Medical University the functions of: assistance, teaching and research are based on the existing relationship between medical practice and medical education, in a planned and organized manner [3]. Currently the National Public Health System is immersed in a process of transformations with a view to increasing the main health indicators with efficiency, rationality and maintaining sustainable development. Process in which all medical universities in the country are immersed.

In this context, the professionalization of the university professor is a priority, a process that must be understood as a continuous and systematic improvement of their academic qualification, which is in no way spontaneous or totally selfdirected, since it requires the existence of institutional strategies that stimulate and guide said process, in addition to the individual interest of each teacher involved [4]. 
In Cuba, the Ministry of Higher Education has established three main teaching categories: assistant professor, assistant professor, and tenured professor. There is also the transitory category of instructor, which are established in Ministerial Resolution Number 85/2016: [5] "Regulation for the Application of Higher Education Teaching Categories". It is essential for the transit through these categories to maintain a satisfactory job as a teacher, as well as to demonstrate knowledge about foreign language and social problems of science, in addition to being active in research, development and technological innovation. These teaching categories are common to all higher education, including Medical education. The training of the faculty in the field of Medical Education is the only possible way to face the current challenges of training human resources in health [6]. The doctor in her role as a teacher has the obligation to prepare and update herself scientifically. To be able to teach medicine, the doctor is not enough with his knowledge of the profession, he must also acquire pedagogical knowledge that helps his knowledge to be transmitted efficiently, so that his students can learn. It is intended that the teacher stimulates learning in their students and teaches them not only to be a passive entity in receiving information but also to actively participate in the search for their knowledge

ISSN: 2574-1241

DOI: $10.26717 /$ BJSTR.2020.31.005086

Claribel Plain Pazos. Biomed J Sci \& Tech Res

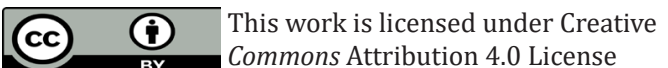

Submission Link: https://biomedres.us/submit-manuscript.php aided by the teacher's guidance and current scientific technical development. The answer to the need of the contemporary world lies in the formation of the professional human capital necessary from the professionalization of teachers.

\section{References}

1. Ministerio de Educación Superior. Breve resumen de las carreras que se estudian en la Educación Superior en Cuba: Ciencias Médicas. Medicina. Carreras Forodebate.

2. Segredo Pérez AM, Rigñack Ramírez Ll, García Nieblas RM, Perdomo Victoria I, León Cabrera P, et al. (2015) Evaluación del clima organizacional en instituciones docentes de la Universidad de Ciencias Médicas de La Habana. Educ Med Super 29(3).

3. Segredo Pérez AM (2019) La gestión universitaria y el clima organizacional. Educ Med Super 25(2): 164-177.

4. Verdecia EA (2019) Retos de la educación en las ciencias médicas de Mayabeque. Medimay 25(3): 178-181.

5. Cuba, Ministerio de Educación Superior (2017) Resolución Ministerial No. 85/2016 del 17 de octubre del 2016. Reglamento para la aplicación de las categorías docentes de la educación superior. Gac Of Repub Cuba p. 5.

6. Díaz Rojas PA, Leyva Sánchez EK, Carrasco Feria MÁ (2019) El sistema de formación escalonada en Educación Médica en la Universidad de Ciencias Médicas de Holguín. Educación Médica Superior 33(1). 